\title{
Translated Literature in the Russian Culture of the 20th Century: Manipulation and Censorship
}

\author{
Natalya V. Klimovich* \\ Siberian Federal University \\ 79 Svobodny, Krasnoyarsk, 660041, Russia
}

Received 10.01.2017, received in revised form 18.12.2017, accepted 15.01.2018

The article is devoted to the study of the phenomena of manipulation and censorship in the Russian literary culture of the $20^{\text {th }}$ century. Finding connection between institutional censorship, determined by the state policy in different countries and manipulation, the author identifies possible scenarios of conscious and unconscious manipulation. Based on the examples of the existing translations of fiction from English into Russian the manipulative strategies, used by translators to deal with the censorship restrictions are identified.

Keywords: translation, conscious manipulation, institutional censorship, individual censorship, rewriting, manipulator.

DOI: 10.17516/1997-1370-0209.

Research area: philology, translatology, culturology.

\section{Introduction}

Literature, and, in particular, translated literature for centuries has been a subject of censorship, that was determined by the ideology of the ruling party or the state leaders. Institutional censorship inevitably leads to manipulation as, trying to comply with the specific requirement of censoring agencies, both the source text authors and, consequently, translators produce the texts in accordance with specific restrictions set by the existing ideology.

Ideological factor, as one the most important reasons for manipulation in translation influences the personality of manipulator in translation. Under different circumstances both the initiator of translation and the translator act as manipulators.
Initiator, as conscious manipulator, often connected and belonging to one of the censoring agencies, determines and controls the process of translation, expecting the text that does not violate the existing ideological norms. Translators acts as conscious manipulator in case of choosing and initiating the process of translation, distorting the text due to their ideological views. Unconscious manipulation takes place due to translator's lack of experience or knowledge.

\section{Problem Statement}

History abounds with the examples of translations censorship, at that, the texts of various genres - canonical texts, the works of mass culture and even children's literature become its object:

(c) Siberian Federal University. All rights reserved

* Corresponding author E-mail address: klimovich7979@mail.ru 
"The Prince" by Machiavelli (banned in France in 1576), "One Thousand and One Nights" (banned in the USA in 1927), "Uncle Tom's Cabin" by H. Beecher Stowe (banned in Russia in 1852), "Alice in Wonderland" by Lewis Carroll (banned in China in 1931) and many others.

The official reasons for these bans were very different and largely depended on the cultural and political peculiarities of the respective national context. But we can say that they were mostly connected with the moral acceptability of the text. For example, in 1857 "The Obscene Publications Act" was released in the UK, which marked the beginning of the official censorship of texts, considered as offensive for the English reader.

Not only separate texts are subjected to censorship: institutional censorship may officially ban a text not only because of its content but also because of the personal data of the author or translator. For example, translations of Thomas Mann and Andre Gide were banned in Fascist Italy, because they were considered Jews. Mussolini's regime, as well as the Government's desire to promote the dissemination of Italian culture led to the fact that the Ministry of Popular Culture (Ministerio di Cultura Popolare) introduced the strict laws regulating the translation work. Thus, the publishers were obliged to inform the Ministry about each publication of foreign books translations and ask for permission to do it. Moreover, the translation of all the works of fiction and entertainment publications were published in limited editions and carefully edited.

Similarly, entire genres can be exposed to censorship. In Fascist Italy and Nazi Germany detective stories translations were banned in the latest years of the regime because of their popularity among the readers: authorities considered that the detective stories contain numerous examples of immoral and anti-social behavior. For this reason, censorship considered necessary for the preservation of all the related elements of Nazi ideology and protecting people from the "hidden" influence.

In the 1930s there was no harmonious system of book production and translations control. After 1933, publications and, in particular, translations control became more regulated, and prior censorship was introduced. Censorship, organized within the frames of Goebbels' Ministry of Propaganda and the Gestapo, was invisible to readers: it involved "limiting the number of books available for sale and in libraries".

Since the beginning of the war, all the translations from the opponents countries were subjected to strict censorship or banned, which was intended to prove the inferiority and hostility of foreign culture in comparison with the German one. In the later editions the translations from French and English were replaced by the "friendly" nations' languages translations. It should be noted that the Nazi repression affected not only the literary translation, but also other arts related to translation work, such as theater. In Nazi Germany translation was considered as a threat and a dangerous tool that contributes to culture obstruction with alien elements. Unwanted for the regime translations were, in practice, censored or banned, and translators and publishers were often expelled from the country or destroyed.

In Spain, cultural censorship under the Franco regime, which sought to preserve the regime ideology and the isolation of Spanish culture from foreign influence, played a paramount role. To achieve these goals, censorship was consistently carried out by three agencies: the Book Censorship section, the Cinema and Theater Department and the Information and Censorship section. All the three bodies had the power to impose a ban on any work of art, which posed a threat to the regime's ideology.

Dubbing played an important role in Spanish film industry. It was an "ideological tool for strengthening nationalist sentiment by imposing, 
unification and standardization of the national language". The original sound recording in films was erased, and access to other languages was limited. Thus, the government of Franco sought to eliminate foreign influence and create the illusion of the fact that the censored foreign film was created in Spain in accordance with the Franco's standards.

Jeroen Vandaele believes that the Franco censors imposed foreign comedies their own ideas of humor (Vandaele, 2002), and provides two examples of censorship in the comedies of Billy Wilder "The Apartment" and "Some Like It Hot". Both films had a huge commercial success in America and in Europe. However, many elements of the films, such as extramarital affairs, suicidal tendencies and alcohol were the taboo subjects, that were instructed to exclude. As a result, humorous component suffered heavily: only a few "immoral" fragments were preserved. That is, ultimately, both films underwent significant changes.

\section{Point of View}

The phenomenon is virtually of universal nature, as in the eastern countries literary works and translations were also subjected to censorship, for example, literary inquisition and censorship in China, censorship in the Arab countries, etc.

Censorship, as a system of state supervision over the press and media communication is carried out in accordance with a set of specific values and criteria set by the supervisory authority. There are 2 types of censorship: institutional censorship censorship is established by state and individual censorship - censorship is established by an individual.

The function of institutional censor in the Soviet Russia was performed by the Main Administration for Literary and Publishing Affairs established in 1922, which carried out its activities up to 1991. Glavlit gave permission for the publishing houses establishment and affirmed candidates for management positions, permission to issue periodicals, selected editorial boards and editors-in-chief. This body also controlled broadcasting, exhibitions and public lectures. Glavlit restricted and controlled the acceptance of books from the public by the secondhand bookshops, controlled censoring agencies in the territory of the USSR, was responsible for organizing preliminary and subsequent control over all kinds of printed works and broadcasting; controlled import of foreign literature into the Soviet Union and export of Soviet literature from the Soviet Union to other countries, etc.

Annually Glavlit made a rough plan of publishing products for the whole country, defining the number of pages and determining the percentage of literature on various subject areas and for the certain groups of consumers. The plan was approved by the board of the People's Commissariat for Education (later - the relevant ministry).

Glavlit also monitored the implementation of the approved plan and exercised primary censorship of books and periodicals in the country and all the imported literature.

Thus, in various countries in different historical periods, some literary works were not translated at all, or were translated in accordance with specific requirements. One of the examples is the translation policy adopted in the Soviet Union, when, due to the state control, the party control and imposed censorship some literary texts that contained unwanted information such as allusions to religious themes, were translated with numerous alterations or omissions.

The functions of censorship were assigned to specific state institutions. Censorship controlled all domestic official channels of information dissemination: books, periodicals, radio, television, cinema, theater, etc., and the information coming from the outside (the jamming of foreign radio stations broadcasting in the languages of the peoples of the USSR, scrupulous control of printed products of foreign mass media on the subject of "anti-Soviet" propaganda). 
The phenomenon of censorship almost always inevitably leads to manipulation in translation. Manipulative translation studies that emerged in the 1980s based on the works by G. Toury, J. Lambert, D. Holmes and I. Even-Zohar, dedicated to comparative literary studies, is the subject of research by many translation theorists and practitioners. The name "Manipulation School" of translation appeared after the anthology titled "Manipulation of Literature" published in 1985, edited by T. Hermans. Such researches as A. Lefevere, S. Bassnett, A. Dukate, V.-L. Inkeri， A.M. Kaplunenko， E.Y. Kunitsyna, N.G. Kornaukhova study manipulation in literary texts.

The Manipulation School representatives claim that every translated text is a result of manipulation of the source text by the language and culture of the target text and manipulation in fiction is inevitable.

There is a belief shared by both the Manipulation School theorists and professional practicing translators that in the process of translation both the translators themselves and, accordingly, the target audience are subjected to manipulation. One of the important issues related to manipulation in translation is the question why the interpreter misinterprets and distorts the original text, and who is the manipulator in the translation?

Translation theorists identify two kinds of manipulation. Manipulation, which is caused by ideological, economic, social, political and cultural factors happens consciously and can be defined as conscious manipulation. Manipulation taking place due to the low professional level of the translators, their ignorance and inability to properly and fully accept and decode the information of the original text can be defined as unconscious manipulation.

According to A. Lefevere the translator is also influenced by many other additional factors including age, gender and translator' experience, as well as translation's position in the culture.

Christiane Nord introduces the concept of initiator in translation, which plays a key role in the translation process. In addition to the fact that this person has a certain set of characteristics, the initiator is also the person who starts the translation process and determines its course. Thus, the process of cross-cultural transmission of the text starts because the initiator needs a certain communicative tool - the original text. This means that the initiator needs a text translation for a particular purpose. The choice of the original text by the initiator or any other person, as well as the purpose of a text translation determine its translation strategy.

Thus, the strategy, which the translator follows, is determined by the communicative needs of the initiator. In practice, before starting work with the source text, translators are generally instructed on how to work with the text and the translation process will inevitably be determined by this information, even if the translator tries to do everything possible to translate the text as close to the original as possible. Accordingly, the initiator who activates the translation process, and determines the strategy, which the translator follows and influences it, may be a manipulator.

In case of manipulation in translation, the author of this paper proposes several possible scenarios:

1. The translator himself acts as a manipulator, distorting the original text. Translators, including translators of fiction, interact with different cultures. However, the translators themselves, in most cases, are the representatives of one of these cultures - the culture of the target language, which determines the level of adaptation of the source text to the target language. When the translator's strategy is defined by the culture (ideology) of the target language, the translator will inevitably adapt the source text, acting as the manipulator. In some cases, it happens unintentionally, and is determined by the low professional level of the translator.

2. In the case when the author produces the text with an intention to deliberately manipulate the reader, the author acts as a manipulator of the 
source text. Under these conditions the translator becomes the unconscious manipulator, as the text they translate will also manipulate its readers in the target language, but, in contrast to the author, the translator does it unconsciously, he/she only reproduces the original text that has manipulative functions.

3. In case of conscious manipulation the fact that the translator acts as the creator of the text for the target culture by adapting the author's text in order to obtain a communicative tool for the target culture is of paramount importance. However, in the case of conscious manipulation, the translator is under pressure, as well, i.e. he/she is an object of manipulation. There arises a question: who manipulates the translator? In this situation, the initiator of translation acts the manipulator (C. Nord), as this person or institution uses its influence to control and/or influence the translation process. The aims and intentions of the initiator are determined by cultural norms and political situation in the country, i.e. ideology.

One of the possible manipulative strategies used under the conditions of censorship is "translation-rewriting". One of the interesting examples of rewritings includes "The Golden Key, or the Adventures of Buratino" (1936) by A. Tolstoy. However, in Tolstoy's version the original story underwent direct ideological changes. A. Tolstoy omitted most details which would be considered too gruesome or too moralistic. Unlike Pinocchio in the original story, Buratino never shifts to right behaviour and does not become a real human. Quite the contrary, he is rewarded for rather not following the rules of what is assumed to be right behaviour as being nonconformist. As one of the most successful children's stories introduced into the Soviet environment, "The Golden Key" depicts the values of the system under which it was written, including abolition of private property, the importance of collective labour, and the idea of equality and socialisation.
Another example of ideological rewriting is "The Wizard of the Emerald City" (in translation by Peter L. Blystone "Tales of Magic Land") is a children's novel by A. Volkov. The book is a renarration of "The Wonderful Wizard of Oz" by L. Frank Baum. A. Volkov changed the names of most characters, removed some elements of Baum's novel and added some new elements. He "allegedly cleansed the work of its capitalist undertones and imbued it with healthier communist values, thereby creating a new story, suitable for Soviet children" (Haber: 257). The rewriting was in line with Russian culture of the time: to befriend and help others (the ideology of the Pioneer organization), the idea that the prosperity of the minority is built upon the exploitation and deception of the majority, addition of a revolutionary strain to the story (Elli asks why the people haven't risen up against the wicked sorceress Bastinda), friendship, companionship, love of homeland and the collective struggle for freedom.

The poetry by R. Burns undergone serious changes. Under Soviet ideology previous translations of Robert Burns made in the nineteenth century could no longer fulfill the new aesthetic function of literature. New translations of Burns' poetry would have to include a positive revolutionary hero, heroic acts, optimism, references to communist slogans, and so forth (Vid, N.). New translations were performed by S.Ya. Marshak who became the only official translator of Burns' poetry in the Soviet Union to present Robert Burns' poetry to Soviet readers in a more appropriate way. He avoided dialect expressions to deprive Burns' poetry of its Scottish coloration; all the religious inks were ignored and there were no translations with religious motifs except satire; the images of beggars and robbers were idealized; the poems to Burns' friends - aristocrats, as well as poems describing political situation in Scotland and England were not translated due to ideological reasons.

"Robinson Crusoe", a novel by Daniel Defoe was subjected to serious changes as well. Its 
abridged retelling of 1920 s by K. Chukovsky "The Life and Astonishing Adventures of the Seafarer Robinson Crusoe" became the most popular version in the Soviet Union. The translated novel, in line with Soviet practice, doesn't contain Christian references; Crusoe's father is depicted as a harsh and cruel man with little or no affection for his son, whereas in the original the father promises to pray for his son's welfare and demonstrates considerable affection and concern.

Deletions and omissions were also common in the translated texts. Even when the original versions were not rewritten the texts were subjected to ideological censorship.

"Lady Chatterley's Lover", a novel by D.H. Lawrence, first published in the Soviet period 1928 was first translated into Russian in 1932 by T. Leshchenko-Sukhomlin and I. Bagrov and M. Litvinova. Containing not only sexual scenes, but obscene words and religious links the novel was not easy to translate under conditions of strict censorship and ideological influence. The translations into Russian deprive Lawrence's language of its peculiar character. Thus, critics write of emasculation of the Russian version, as in comparison with the original version it became more ceremonious due to deletion of the so-called "four letter words" and obscene lexis.

Other examples of deletion or omission include biblicisms - words, quotations and idioms that originated from the Holy Scripture. For example, John Steinbeck's "The Grapes of Wrath", an American realist novel that describes difficult life of a poor family of American tenant farmers driven from their home by drought, economic hardship, agricultural industry changes and bank foreclosures forcing tenant farmers out of work. Although the plot was in line with the Soviet ideology, the novel contains numerous quotations from the Bible, as the family was very religious. A large number of biblicisms were omitted in the translation of the novel by N. Volzhina (Klimovich, 2015). The fact led to changing the meaning of some parts of the text as well as emotionality and expressiveness of the original version that was lost for the Russian reader.

Omissions of the religious context also take place in D.H. Lawrence's "Sons and Lovers", "Tess of the D'Ubervilles" by T. Hardy, "The Forsyte Saga" by J. Galsworthy and "An American Tragedy" by T. Dreiser where plenty of deletions were made due to ideological and political reasons.

In some cases "undesired" content was not deleted but substituted by a synonym or an analogue. This technique allows to get rid of the words and expressions that do not comply with ideological requirements. At the semantic level the substituted phrase/word has the same meaning, but, in most cases it changes expressive content of the original text.

Substitutions are standard for the translations of the Soviet period. Words are substituted by synonyms-analogues (Klimovich, 2015). Thus, in "The Portrait of a Lady" by Henry James (Russian translation by M.A. Shereshevskaia and L.E. Poliakova) an idiom to make a scapegoat of $s b$. is obviously identified by the translator, but was consciously substituted with the verb omыгрывается (take it out on). The Mammon symbol of greed in J.Lawrence's translation of "Lady Chatterley's Lover" and prophesy in J. Stainbeck's "The Grapes of Wrath" are substituted with their semantic, but not expressive equivalents мошны (heavy purse) and видеть нaneped (foresee) correspondingly in the Russian translated versions.

Although the original texts were distorted and "forbidden" elements and structures are substituted with their semantic, but not expressive equivalents, getting rid of the undesired biblical link the translators managed to keep equivalence with the original texts at the semantic level.

Even interjections with biblical links were substituted with their analogues. Thus, in 
J. Stainbeck's "The Grapes of Wrath" it is possible to find the following examples of substitution: $M y$ God-нy; By God - Дa, etc. The technique used for the translation of interjections changes the source text both at semantic and expressive levels.

Antonymous translation is manifested through giving opposite meaning to a word or an expression in the translated text. Under condition of ideological manipulation negative connotation was given to the words and phrases that were supposed to be changed. Such phenomena occurred with proper names originated from the Bible and interjections with proper names from the Bible.

For example in J. Stainbeck's "The Grapes of Wrath" proper name Jesus H. Christ and God Almighty were translated as чёpm (devil). As for interjections, by God was translated as Эx, черm; Holy Jesus as Ax, черm, etc. This technique allowed to keep Biblical link of the source text, but gave negative connotation to the positive statements. Thus, having recognized intertextual elements the translator, following the Soviet ideology conveyed them with the negative analogues, changing expressive content of the main characters' statements and, consequently, readers' perception.

\section{Conclusion}

Thus, playing the key role in the process of fiction translation in the $20^{\text {th }}$ century, censorship, determined by the policy of the ruling party, was the main reason for ideological manipulation in the literary texts translations in the Soviet period. The proposed scenarios for identifying the personality of manipulator in translation suggest that under different circumstances both the initiator and the translator act as manipulators.

Censorship and ideological influence generated the identified manipulative strategies that include rewriting of a literary work, deletions of the "undesired" elements in the target texts and substitutions with either synonyms or antonyms. All the strategies distort the source text at the semantic, pragmatic and expressive levels, delivering this product of manipulation to the target reader.

\section{References}

Bassnett, S. (2000). Constructing Cultures: Essays on Literary Translation; Susan Bassnett, Andre Lefevere. Clevedon, Multilingual Matters Ltd, 143 p.

Even-Zohar, I. (1978). The Position of Translated Literature within the Literary Polysystem, In Literature and Translation, 117-128.

Dukate, A. (2007). Manipulation as a Specific Phenomenon in Translation and Interpreting, Available at: http://www3.acadlib.lv/greydoc/Dukates_disertacija/Dukate_ang.doc

Jacques, T. (2002). Ideological Transformation Though Translation, In NUCB JLCC 4 (1), 13-

19. Available at: http://www.nucba.ac.jp/themes/s_cic@cic@nucba/pdf/njlcc041/02JAQUES. PDF. Accessed 30.08.2016.

Klimovich, N.V. (2015). Manipulation in Translation (Exemplified by the Intertextual Elements' Translation), In Journal of Siberian Federal University. Humanities \& Social Sciences, 2 (8), 244-251.

Kornaukhova, N.G. (2009). Manipuliatsiia v perevode: mif ili real'nost'? [Manipulation in Translation: Myth or Reality?], In Translation in the Era of Post-Modernism: Scientific Papers Collection, Irkutsk, ISLU, 36-43.

Kornaukhova, N.G. (2011). Perevod vs. versiia: vidy manipuliatsii v khudozhestvennom perevode [Translation vs. Version: Types of Manipulation in Literary Translation], In Bulletin of Irkutsk State Linguistic University, Irkutsk, ISLU, 176-183. 
Lefevere, A. (1992). Translation, Rewriting and the Manipulation of Literary Fame. London, New York, Routledge, $176 \mathrm{p}$.

Nord, C. (2003). Function and Loyalty in Bible Translation, In M. Calzada-Pérez (ed.). Apropos of Ideology. Philadelphia: Multilingual Matters, 89-112.

Razumovskaya, V.A., Klimovich, N.V. Manipuliatsiia pri perevode intertekstual'nykh elementov $\mathrm{v}$ khudozhestvennom tekste [Manipulation in Intertextual Elements Translation in Fiction], In Bulletin of Moscow State Pedagogical University, Philology. Theory of Linguistics. Linguistic Education, 2016, 2 (22), 55-63.

Schjoldager, A. (1995). Interpreting Research and the 'Manipulation School' of Translation Studies, In Target, Interpreting Research, 29-45, available at: http://download2.hermes.asb.dk/archive/ download/H12_04.pdf

Toury, G. (2000). The Nature and Role of Norms in Translation, In The Translation Studies Reader, ed. by L. Venuti. London, Routledge, 198-211.

Vandaele, J. (2002). Humor in Translation, 147-152. Available at: http://folk.uio.no/jeroenv/ Vandaele\%20Humor\%20in\%20Translation_proofs.pdf

\section{Переводная литература в русской культуре XX века: манипуляция и цензура}

Н.В. Климович

Сибирский федеральный университет Россия, 660041, Красноярск, пр. Свободный, 79

Статья посвящена изучению явлений манипулячии и иензуры в русской литературной культуре $X X$-го века. Обнаружсивая связь между институциональной цензурой, определяемой государственной политикой различных стран и манипуляцией, автор выделяет возможные сценарии сознательной и бессознательной манипуляции. На примере изданных переводов художественной литературы с русского языка на английский определяются манипулятивные стратегии, используемые переводчиками в условиях иензуры.

Ключевые слова: перевод, сознательная манипуляиия, институциональная цензура, индивидуальная цензура, перевод-переложение, манипулятор.

Научная специальность: 10.00.00 - филологические науки, переводоведение, 24.00.00 культурология. 